\title{
RELIGION AS A WAY OF BRANDING IN THE AGE OF CONSUMERISM
}

\begin{abstract}
Purpose - taking into account, that consumption of spirituality and more precisely brand religion in development of the market has been well acknowledged as well as it has been largely abandoned in secular consumer society. The aim of this paper is to explore the theoretical concept of this phenomenon and search for the answers in regards the symbolic brands and fiddled in religious rhetoric to build a narrative tradition for example the symbolic brand, and establish a community of loyal followers, which sticks strong. How do people adjust their religious and spiritual beliefs and practices in such a society? What are the limits to marketing and branding religious and spiritual goods and practices?

Design/methodology/approach- the research implements a qualitative exploratory approach using cases of symbolic brands. It explores the causes of religious consumer society and the most common personal adjustments (quality expectations, syncretism, religious shopping) and organizational answers (marketing and branding strategies the theoretical concept of consumer ambiguity and its influence on affect. Our goal is not to test any theory, nor to apply the scheme to any particular phenomenon. Rather, we show that very different ideas and examples about, as branding of religion, quasi-religions, religious-secular competition could be combined into one conceptual scheme.

Finding - the research demonstrates the limitations and difficulties for religious marketing and branding. In fact, religious marketing and branding may not be accepted by the organizations' members and/or by the public in general. Finally, marketing and branding may stumble upon the difficulty that transcendent claims are increasingly difficult to sustain in modern societies.

Research limitations/implications - it is acknowledged that the current research is limited by its exploratory nature, however, it highlights that consumer's search of religion in brands should not always be viewed as negative and provides important insights into the consumption of spirituality and the pursue of the meaning in the life.

Practical implications - First, consumption of spirituality in marketing has been poorly researched in recent times. The current research found that individuals did embrace the market in this area and enjoyed the symbolic meaning in branding inherent in many of the products/services on offer. Second, has been niggardly studied in societies in which brand community flourishes. The current research has contributed to this literature through findings, which reveal that we see that modernization creates rules according to which individuals have the right to choose, gives them the resources be able to make choices, and provides representations and values that legitimate religious consumer behavior or new open space for new believing systems.

Originality/Value - the theme and the research is not very popular among marketing and sociology researchers and the dangerous of these specific belonging and loyalty to certain brand as religion- still not discovered what an output it will provide to society.
\end{abstract}

Keywords: branding, religion, society, symbols, believes.

JEL classification:

Z12 - Religion

D12 - Consumer Economics: Empirical Analysis

\footnotetext{
${ }^{1}$ Mykolas Romeris University, Lithuania, e-mail: g.kriauciunaite@mruni.eu
} 


\section{Introduction}

Brands are the equivalent of religious objects... Branding is similar to religion as it aims to create the experience of an affective community. Brand management is the economic use of religious element (Arvidsson, 2006).

The current age has been marked by changing technologies, constant transformation and movement where stability demonstrates the lack of adjustment, incapability to flow with the crowd. It has been a long time that individuals are continuously tempted by brands (goods), services, experience, travels or the places where we should live. Modern society is often named as a consumer society, where core values are based on individualism, free choice and the value of markets relations. In this kind of context, it becomes difficult to understand the meaning of religion, although it has survived plagues, scientific revolutions (scientism), "tyranny of the mind" as well as modernism. Therefore, through undertaking new perception(s), brand(s) became similar to religion, which has a system of practices (or rituals), community of believers, a leader, a belief system and sacred classifications. This definition of beliefs was defended by sociologist Émile Durkheim: "states of opinion and consist of re-presentations" (Durkheim 1995) that express the nature, history, and powers of sacred things, including their relationships with one another and with profane things. They establish worldviews and give meaning to a person's life and, as such, form a part of an individual's identity. Rites and rituals are "particular modes of action," characterized "by the special nature of their objects" (Durkheim 1995). They symbolically connect the spiritual and the material world, reinforce community's core beliefs, justify or challenge the existing social order, and unite a moral community.

The daily relationship with goods (brands, luxury possessions) has intensified more than ever, where the connection with the "other" have changed the relationship with the brand. Individualism and indifference have conquered the present age, with the development of value pluralism, transformation of worldviews and social indifference, which additionally creates different perceptions of religion. This change in the development of the society became obvious when individuals experienced emptiness in one's living, constantly seeking happiness, emotional comfort, support, or even marketplace spirituality as our ancestors have sought in the Church, inspired by the promise of salvation proclaimed in advertising or supermarket. Developments of modern religiosity is often countered by ancient perspectives that could potentially channel new forms to flourish" (Taylor, 2007). Individuals and status could bring collective secular phenomena and even commercialized brands in order to appease the desire of an enthused society (Muñiz, O'Guinn. 2001)

\section{Theoretical background}

\section{Understanding of Religion}

In present post-modern culture, we often fail to identify religion in our own society when it lacks an institutional or creedal form, and is disguised under various cultural forms (Jindra 2000). Fortunately, although combined with secularization, rationalization and dissatisfaction, it does not often result in a society that lacks religious phenomena, rather one that is absent of traditional religious phenomena. They are being constructed by new, as Bauman used to name it liquid forms of religion, according to Bauman will have to be approached form a new analytical perspective (Bauman, 2001). From this stance, we can consider religion as a cultural symbol-system reactive to difficulties of meaning and 
coincidence through reference to a transcendent reality, which influences every-day life but is not directly controlled. Religious symbol-systems incorporate mythical, ethical, and ritual elements as well "salvation goods" (Weber, 2012; Geertz, 1993; Pollack, 1995; Riesebrodt, 2010). While they are symbol systems, and others responsive to problems of meaning and contingency, they still lack the link to the transcendent reality. Islam, Christianity, Judaism on the other hand, are clear established religious systems from this definition. As demonstrated later on, the main difference between religion and non-religion is variety, hence making it possible to highlight a hybrid or quasi-religion systems (Stark, Finke, 2000). This attitude is often called the "supply-side approach" because it contends that the necessity of religion across all societies is fundamentally stable and that differences in aggregated religiosity can be explained by variation in the supply of religion. Authors consider society as a potential religious market that has been regulated. Individuals are seen as "naturally religious" and will act as religious and spiritual shoppers, only if they are allowed to do so. People choose religious beliefs and practices according to their preferences - as much as they choose cars or toothpaste (see: Chaves, Gorski, 2001; Voas et al., 2002). To that extent, we will look more precisely to a new religious based phenomenon - consumerism alike religion.

\section{Consuming as the New Religion}

Nowadays, consumerism is viewed as the culprit and main facet of modern culture. Consumerism is responsible for eating disorders, influenza, depression, cultural icons, political corruption, commercialization of holy celebrations like Christmas, and short attention span of our youth. In other words, commercialism is a mirror rather than a lamp (it reflects and does not enlighten the problem of society). However, consumerism has some positive effects- it creates rituals, such as those in a community, family or the country itself. For instance, we do not buy presents just for ourselves. By buying for others, we try to standardize certain virtues. While looking at consumerism from this angle, we need to take into account that this access to material life happens via advertising, branding and packaging (Twitchell, 1999).

Our lives are constantly surrounded by things, we exchange things, we buy things, we steal things, and we hoard things; all of these things fuel our inner happiness. Kasser (2002) elaborates on this argument by stating that the reason why materialism is concerned with transcendental happiness is due to the fact that contemporary society materialism main focus is the human soul. Marketers are seducing not just our need for necessary commodities, but they are providing spiritual meanings behind these products. The process of buying then becomes an unexpected process of worshiping and filling empty voids for customers. Kasser (2002) observes that: "not only must we work harder, but once goods are possessed, we have to maintain, upgrade, replace, insure, and constantly manage them". It seems that in this situation a person replaces his inner emptiness or lack of spirituality with goods, believing that these goods represent happiness and spirituality. Consumerism gives the impression of feeling spiritually full. It replaces our inner wish to be more than we are, by simply wanting more. The only reason why consumers put themselves in this cycle: buy, use, throwaway and repeat, is because it potentially makes them happy or even happier than they already are. Consumer culture fuels the belief that the only way to be happy is through shopping and filling our surroundings with goods. The question is how far will it go until it becomes the only one purpose and a meaning in the life?

The societal changes mentioned have had various effects on individuals which are characteristic of "religious consumer society". There are three such effects: changing expectations towards religious organizations, an increase in individualized religion and 
religious shopping, and the possibility that consumption (of all types of products) may itself become a form of religion in modernity.

\section{Research methodology}

The research implements an exploratory approach with in a use of cases of symbolic brands in order to demonstrate how the brand affects the seeking personality and what kind of the message is being sent from marketers as well as how the person perceives it. Sharply saying, barely is consuming religion surveys thou almost a century of scholarly literature on consumerism and the commodification of culture and charts the ways in which religious belief and practice have been transformed by the dominant consumer culture of the West. It demonstrates the significance of this no-theistic cultural shift for theological method, belief, community, and theological anthropology. It explores the causes of religious consumer society and the most common personal adjustments (quality expectations, syncretism, religious shopping) and organizational answers (marketing and branding strategies the theoretical concept of consumer ambiguity and its influence on affect. Our goal is not to test any theory, nor to apply the scheme to any particular phenomenon. Rather, we show that very different ideas and examples about, as branding of religion, quasi-religions, and religioussecular competition could be combined into one conceptual scheme and the small part of the effect of it.

\section{Brand's Religion}

According to Canadian journalist and columnist and, at present, one of the famous social writers on a theme of branding and advertising Naomi Klein, "branding is about a global lexicon of imagery, music, icons" (Klein, 2002) and in this fashion, it transfuses a code into our brains. Branding, as a new member of the community - even leadership with companies such as Nike, Benetton, and Starbuck's which have built their brands on meanings such as transcendence, multiculturalism and belonging, respectively, puts spirituality into the market, which offers a permanent, bounded identity, in which you are told about your real self. It suggests an invitation to endless confidence. It promises a new life (Beaudoin, 2007). It can even be seen as derived from Western spiritual disciplines. It proves that "economy as a discipline is not consciously 'spiritual' or 'religious', but it operates with a dynamic similar to classical spiritual disciplines - anonymously" (Beaudoin, 2007). We will see the deliberate use of this by companies.

Brand is not just a name of a company or a product. It represents even more: a myth, a symbol that serves emotional meaning. It is influenced by many aspects, on the one hand, in the case of creating and formulating a brand. In reference to brands, companies raise many questions such as: what is the historical background of the company and country in which the product should be launched? Are there any national or regional thought? What is the brand gender? Does the packaging or presentation reflect the 'norms' of the market? What kind of message, symbol or value does the brand represent? Brands consistent in their promises, images, identity, quality and advertising are the strongest in their class. When a strong brand changes, keeps up with the pace and develop, generate awareness, does it have the ability to create brand preference? As mentioned, brands have to adjust in order to satisfy individual responses and needs (Beaudoin, 2007).

Diminishing thought has taken in account that consumers are emotional beings especially in regard to how they subvert the rationality of action in different ways. For instance: through belief formation - as wishful thinking, through information acquisition 
jumping to conclusions; and through (most importantly) the lack of regard or neglect of thought about consequences - such as lack of concern for more information (Beaudoin, 2007).

Historically, when marketers speak about brands, they refer to the product itself in terms of quality, price and, of course, function. Nowadays it is not enough to sell a product or a service as a meaning should be behind the product otherwise, no attention will be paid to it. "The fact is great brands have personalities; they have attitude and they give greater depth and meaning to that product" (Gobé, 2006), the surroundings, type of advertising or, promotions seen around it. Is it brightly red Coca-Cola, a McDonald's cheese-burger or maybe a cup of Starbuck's coffee? Hence the question raised is what kind of lifestyles are we admiring behind or beyond our surrounded brands reflect our daily life and our personalities, what kind of values and ideals are they creating on us (Gobé, 2006).

It could be presumed, that the branding culture has replaced the religion and could be referred with Marx famous citation "opium of the people" (Raines, 2012). It becomes "a form of alienation; a symptom of social malformation which distinguishes the exploitative forms of capitalist society" (Davie 2007). Scholars convey their cynicism of religion as a tool to persuade and affirm the dominant worldview. They state that the market as the new religious group brand critical and dominant members of society not just with a new name, but with new inspirations, ideas and theology as well (Davie 2007). As an example, especially at this time- Apple and Harley, these companies have been successful declared as 'Brands are symbols', today the economy is not a formal economy in which products are made to compete in rational terms - it is a 'spiritual' and 'symbolic economy' in which what is sold is 'community', meaning, and shared experiences. Rather than reducing religious phenomena to economic terminology. Far from portraying consumers as rational actors seeking to maximize utility, let alone applying this rationale to religious 'consumers', looking at the evolution of marketing is instructive as to how consumerism actually works (Atkin, 2004).

Brand within a context of religion is usually taken as a negative meaning, but it can have a positive explanation clarifying in the same context as Jesus as a kind of brand. For example, Steve Jacobs took an idea as a leader very close to the Jesus in the process of developing Apple brand like Christianity and aaccording to Kahney the Apple brand itself is sacred symbol of the community, protected by the taboo of criticism (Kahney, 2004). The products behave as religious fetishes to Apple devotees, and Apple shops function as temples. Followers complete public pilgrimages to shop openings also private rituals of product unboxing (Pogačnik, Črnič, 2014). First, as the name of the product (brand), Jesus has a corporate identity. It does not speek about the brand Jesus spirituality' as a generic one which can raise the support of any number of outcomes. It is about creating certain types of deeds, a kind of worldview: a world infused by love, properly understood (Gobé, 2006). Second, the term "brand" implies that this is a spirituality over which Jesus exercises proprietary rights" (Wilson, 2008). Not surprisingly, Jesus can be used as a brand. Not long ago the boycott was lifted for a name like that of jeans and despite; the company is still very popular.

Jesus is used as the best example of how brands could be religious in that consumers need to believe and trust in their brands. Gobé states that: "Like people, most brands have definite character and personality. You remember people because of their look, style, intellect, charisma, and involvement in their community" (Gobé, 2006). The iPhone or the "Jesus phone" also demonstrates some common narratives used to present the relationship of religion to technology. The "Jesus phone" is originally packaged as a godlike, all-powerful technology, created the possibility for critique of its infability once limitations to the technology were identified. Setting up a god-like technology gives the device both a rhetorical power and encourages its unmasking as a false god, as it were. As time passes, the attention shifts from the technology itself to its creator, its divine status trasferred from machine to 
man. Jobs' godlike status was supported by the existing rhetoric of the cult of Macintosh. Much like how Jesus in the Christian tradition is perceived as the One who shows the divine truth, Jobs is perceived as a prophet pointing the truth of the purporting superiority of Apple technology (Campbell, 2007).

Another example visualizing Nike as a church (if some people claim that sports are the modern type of religion, it would be acceptable to entitle "Nike" as a perfect example of religion), an icon that constitutes connection with salvation in a special symbolic language. "The 'swoosh' is a true religious icon in that it serves as a representation of reality and as a participant in reality; you do alter all, you have to wear something to attain this special salvation" (Cooke, 2008). This symbol is the gateway from this world to the other, between your existing self and your Nike self (god of fitness), where salvation is the attainment of the athletic Nietzschean ideal: no fear, no mercy, and no second place" (Cooke, 2008). As an argument, it is very clear in the advertising of disabled people, or women in the athletic movements. The same goes with the Apple evangelism and typical approach of Apple zealots, invented by Apple itself in the early 90's. Back then, Apple were not only selling computers, they were introducing people to the Apple ideology-developing intellectual and creative potentials with the symbiotic relationship between a computer and its user. "Through their own participation in this personal quest, Mac enthusiasts experience a temporary escape from the mundane; spirituality is found similar to that of an institutionalized religion" (Lam 2001). As for more, the majority of Apple users, even as the non-zealous, have recommended using Macs to other people (Campbell, 2007) the ideal characteristic of Apple evangelism. As a result of internalization, Apple's own marketing strategies have transformed into value statements adopted by fans that express their religious sentiments in Apple and the philosophy associate with it. Recently it has become characteristic for Apple fans to wait front of their temples, (Apple shops) in order to be first who will adore the newly resurrected device, the iPhone.

Presently the discussion of materialism and consumerism and the possibility to a religion in a very convenient way, such as a shopping mall with the help of advertising is presented. The media in reference to one of the characters in cartoon "South Park" is synonymous to phrase: "Faith is what makes the economy exist, without faith it is just paper money and plastic cards" (Santana, Erickson, 2016). Indeed, branding can be comparable to religion where people begin to get confused about the use of symbols; particularly it becomes insulting and misunderstood by the broader audience. Advertising companies and brand creatures call it "the act of peace", to alleviate some problems. It can remove stigma, sin, guilt, redemption from sorrow, provides resolution and angst (Stolz, Usunier, 2018).

Some examples looking through the different lenses into the perception of the known brands and the message consumer is supposed to receive according to Tiwari (2003) (Table 1).

Table 1. Brands and their message

\begin{tabular}{|c|c|c|}
\hline Brand & Product lens & Consumer lens \\
\hline Revlon & Cosmetics & Selling hope \\
Xerox & Copier & Improving the office, productivity \\
Kodak & Photo films & Memorable moments \\
Pepsi & Cola & Youthfulness \\
British Airways & Airlines & Making people meet \\
Holiday Inn & Hotel & Hospitality \\
Carrier & Air conditioners & Cool comfort in homes \\
Columbia Pictures & Movies & Entertainment \\
Encyclopaedia Britannica & Books & Information \\
\hline
\end{tabular}

Source: Tiwari, 2003 
The branding approach is based on creating a unique and symbolic psychological association and identification between the brand and the consumer. Here, the brand differentiation comes from the brand trying to occupy the unique 'personality' and 'lifestyle' imagery and associations that their target audiences identify with and aspire for (Tiwari, 2003).

Many scholars claim that the nature of branding is the promise within the mind of the consumer (Pringle, Thompson, 1999). Brand "identity" elements (the promise) usually target all of us which is the reason why we buy one product instead of another. What is the message we perceive before we choose? What are companies thinking before creating a brand? What are the main ideas for them?

\section{Spirituality as the Key to Success}

For many people, spirituality replaces institutional religion, associated with loyal tradition and social identities transformed into modernity. Spirituality has become an individual way to demonstrate some religious convictions and it has become a new type of cultural learning to seek a universal way to avoid a natural feeling of anxiety. The term spirituality includes "the intellectual, emotional and relational depth of the human character, as well as the continuing capability and yearning for personal development and evolution" (Benefiel, Delbecq, 2005). What us is the way spiritual messages are used in marketing. For instance, the spirituality of Southwest Airlines (USA) has no relation with religion, but as a demonstration in itself of humour, compassion and relational competence, it shows a clear relation with the idea of spirituality.

At this juncture, where brands and images become more important than the product itself, spirituality is the opportunity to get inside consumers' minds and hearts. Border lining this observation, it is emphasized that: "corporate business interests are served by utilizing the 'cultural capital' of the religious traditions- building upon their authority base" (Carrette, King, 2005).

Spirituality has arrived in the corporate marketplace with a desire to consume. In this context, consumerism is no longer presented as a challenge to traditional religious decorum as items can be purchased wholesale and ignore the corporate links to poverty and social injustice. As long as one is satisfied and have the ability to take care of one's own private spiritual world, one is self-secured in the creation of a place in the nirvana or heaven of corporate capitalism. One can buy the happiness with one's own spirituality, cut off from all the suffering and ills of the world and linked closely to the latest business success" (Carrette, King, 2005).

Spiritual messages have become abnormally popular in the last twenty years in the entire western world and have been considered as a completely normal matter until today. To elaborate on this statement, notable examples from successful companies that sell not just products but also ideas and that the methods done as well.

Example of Nike. Nike had a lot of debates about their advertising with Michael Jordan, the famous basketball player, and in their advertising it seems that with new "Nike" sneakers he can fly. Here, we can find an encoded religious message that "Nike" gives him the possibility to make his dream come true. It is generally agreed that, since then, Jordan has become "Nike incarnate" (Klein, 2010). In this way, Nike presents "sporting transcendence" (Cosper, 2017), "spiritual transformation of Man" (Klein, 2010), and introduces a kind of "messianic" (Klein, 2010) role. The downside of this is that youngsters and children, to whom this is addressed to will believe that if, in this case, Jordan can fly with Nike sneakers, why 
can't they? To elaborate on this idea, Nike's logo - the 'swoosh' - as an icon brings this message to the world that with this symbol on your body you can reach whatever you want. As De Maeseneer (De Maeseneer, 2003) claims, just like the cross in Christianity, which represents the entire system of belief and message to society at large, the same spiritual idea is found in the 'swoosh'.

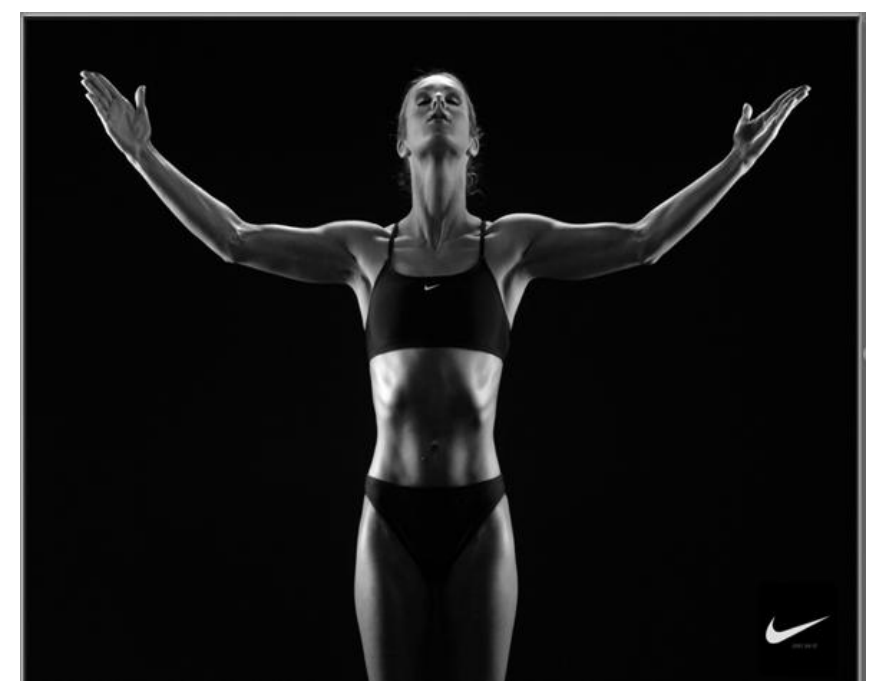

Picture 1. "Sporting transcendence"

Example of Harley Davidson. This is a brand with the negative image of the "Hell's Angels". In its history, it has gained positive attributes by supporting charities and fighting against the immobilizing disease of muscular dystrophy. The appearance of sufferers in their wheelchairs of Harley Davidson's mass rates has been a poignant reminder of the bike rider's freedom on the road, while focusing on the needs of more medical research and motivating the fundraising effort (Pringle, Thompson, 1999).

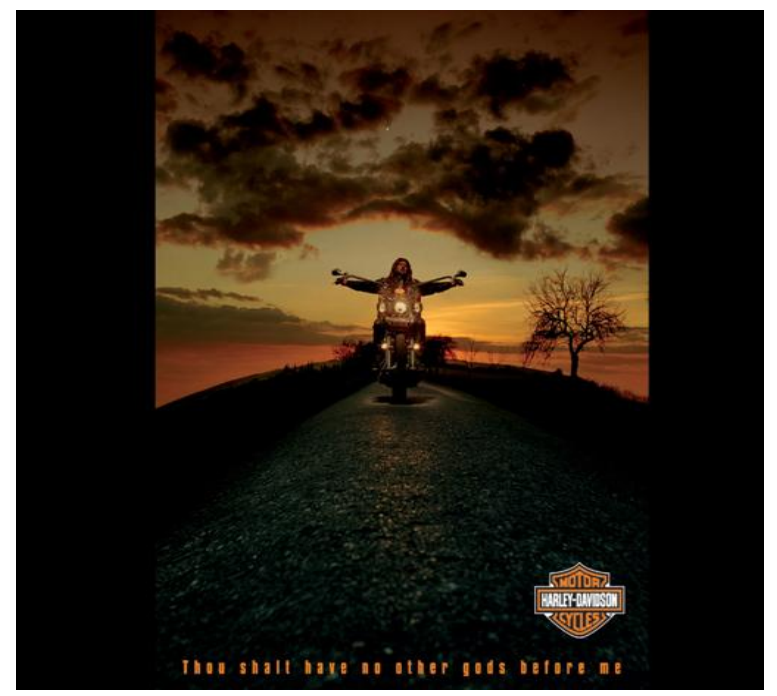

\section{Picture 2. Harley- Davidson "You shall have no other gods before me"}

Example of United Colours of Benetton. This company, into creating of corporate concepts, launched the famous campaign, characterized by images of AIDS-victims, refugees, child labour, racism or a bloodstained Bosnian T-shirt, which gives a direct and oversensitive reaction and a feeling of empathy that Benetton is a very involved company with a secure, 
loyal profile. However, at the same time widely known that this company supports Formula1 (ecological idea becomes a fake). If this is true, the customers are wearing the products of a company for whose involvement in social issues is an empty promise. Then this promise, which is expressed in support of ethnic and disadvantaged poor people favour, will work just for temporarily because it is an empty, commercial promise. As seen in a picture 3 on the next page - the religious message is a hoax, which United Colors of Benetton are using in order to seduce the customer.

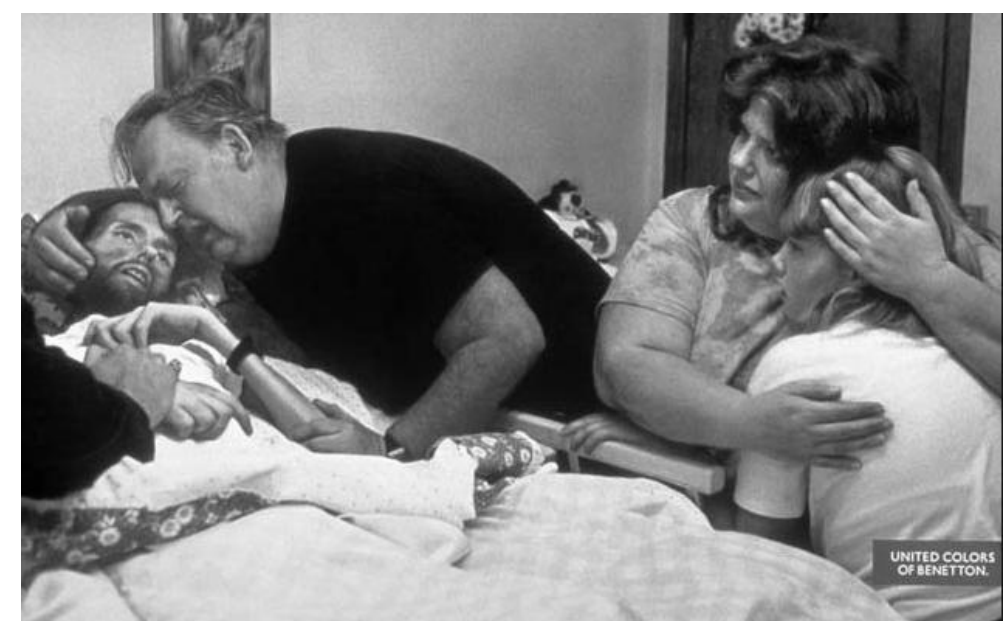

Picture 3. United Colours of Benetton - "Pieta"

Example of Starbucks. Coffee in this age has become by far the most important thing. All mornings start and all evenings end with a cup of this drink, and in between all occasions in the work place or in educational institutions. Starbucks calls itself "a third place, after home and work." It is not just a non-space like McDonalds, "it is an intimate nook where sophisticated people could share coffee, community, camaraderie, connection" (Klein, 2010). It is a place where you come to relax, a sociable gathering spot away from home and work, so it is more than just coffee. What exactly is this company? What do they sell? Everything is about "a meticulously orchestrated approach to both training and inspiring employees who can give the commitment to live, to breathe and thus grow the brand. Starbucks created the experience based on the knowledge about how to treat customers and how to interest them together with the feeling of romance, with a mix of style and elegance.

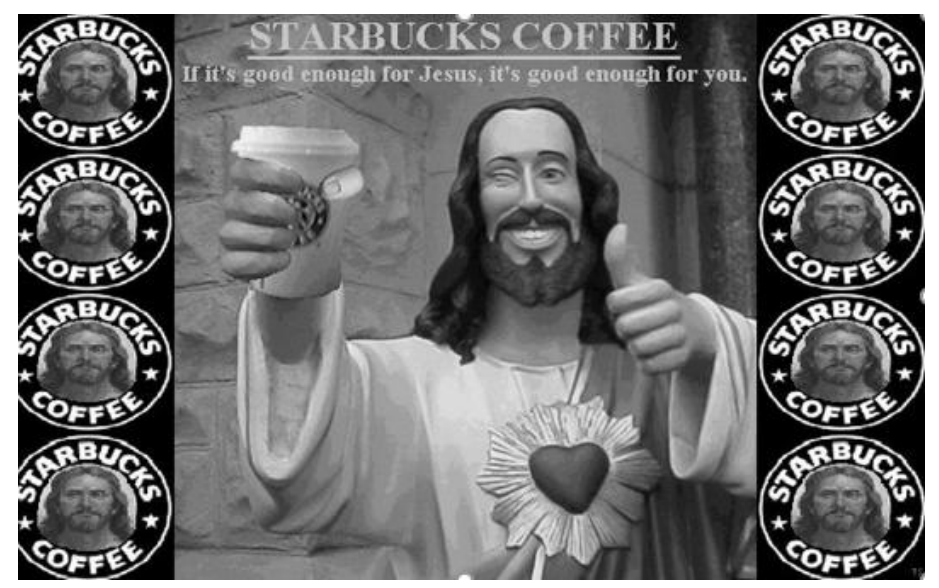

Picture 4. Starbucks coffee and Jesus 
On the whole, these are the concepts that these brands have in common with religion:

- A clear vision;

- A sense of belonging;

- An enemy;

- Sensory appeal;

- Storytelling;

- Grandeur;

- Evangelism;

- Symbols.

\section{Research insights}

In this paper, we have tried to give an interdisciplinary account of the societal causes on individual effects of religious consumer society. As we have seen, brands are symbols around which social communities can be formed. They purpose is to provide the identity, belonging as well meaning. Consumerism flourishes by introducing relations between people and brands involved to certain lifestyles. Consumerism is about personality and rarely on satisfaction. It is not a product (a running shoe, for example) that is being bought, but as we demonstrated earlier, the link to a brand (Nike) and what it symbolizes. It is therefore incorrect to state that religion has become a product on the market in the neoclassical sense. Consumerism is a symbolic economy. Products refer to brands which are symbols inscribed in social relations. This is why the ideal for a brand is to achieve cult status - that is the maximum degree of identifiable, exceptionality as well as emotional power, such that it can become the touch for belonging, identification, community, individual and cooperative emotion, and rituals. Contrariwise, religion inside consumer culture has been reformed as open box of choice, reshaped by the subjective revolution into a lifestyle and a resource for life ethics. This perspective significantly changes the understanding of commoditization.

\section{Conclusions}

Religion and brand faithfulness are all based on faith. Appreciate products shape faith with a help of experience, at the same time it demonstrates an object of faith about the estimation delivered by the product. In order to build the brand religion, it essential to flourish a brand cult, then launching permanent doctrine concerning essential values.

As analysed in this article, in the necessity to fulfil the inner emptiness, advertising provides a promise for a meaningful, wonderful life or eternity as well as salvation through the admiration of idols. From this stance, salvation is a synonymous for ideal or better world most of us are striving. According to this term, it is the matter of branding and advertising (they share the same idea of liberation is portrayed) to spread this promise to society as a whole.

As summarized, advertising is not only a matter of eye-catching pictures or exaggerated phrases. It has transcended into a spiritual message, suggesting not only how to attain happiness, love, health, but also how to fill those religious needs. We have tried to look by raising questions such as - how do they function? What kind of reactions receives from society and how marketers get their results out of this phenomenon?

One of the findings from the research indicates that religious messages not only serve as a means to sell products, but also creates a symbolic community based on a quasi-religious cult of the brands. Marketers from popular branding companies have demonstrated that the way in which brands are commercialized is a method of seducing suspicious clients, through 
illusionary religious promises (suggesting that buying these products leads to happiness, eternal life or salvation). In this research paper, clarification is made about the influence of the consumer society on contemporary culture.

For the future study, it is recommended that a deeper analysis is done on one or more than one area of brand research. Unfortunately, not many researchers have recently explored this topic, especially in the field of sociology (theology, philosophy even marketing). It is aspired to continuously do future and broader research, which could explain other problematic methods of advertising in connection with spiritual messages and the new trends of socially responsible companies aiming to broaden the feeling that a brand can replace costumer inner emptiness. For this to be done, it will become essential to measure this phenomenon through a qualitative study which could a clearer point of view especially in regard to the results of the main brand seekers/ believers, their motives to belong in these kind of groups, and the necessity to replace the spiritual need to belong to a specific community and their values behind these motives. From the marketing point of view, it would be an interesting research via the method of visual communication, the perception of our brain in advertising combining with our natural state of reacting to religious advertising.

\section{References}

1. Arvidsson, A. (2006). Brands. Meaning and Value in Media Culture. London: Routledge.

2. Atkin. D. 2004. The Culting of Brands: Turn Your Customers into True Believers, Portfolio, Penguin, New York,

3. Beaudoin, T. (2007). Consuming Faith-Integrating Who We Are with What We Buy, Rowman \& Littlefield.

4. $\quad$ Benefiel M., Delbecq A. L. (2005). Soul at Work: Spiritual Leadership in Organizations Dublin: Veritas.

5. Campbell, H. (2007). What hath God wrought: Considering how religious communities culture (or kosher) the cell phone. Continuum: Journal of Media and Cultural Studies 21(2): 191-203.

6. Carrette, J., King, R. (2005). Selling Spirituality: The Silent Takeover of Religion. London: Routledge.

7. Cosper M. (2017). Recapturing the Wonder: Transcendent Faith in a Disenchanted World.

8. Cooke, P. (2008). Branding Faith: Why Some Churches and Nonprofits Impact Culture and Others Don't. Ventura: Regal Books.

9. Davie, G. (2007). The Sociology of Religion. Los Angeles, CA: Sage.

10. De Maeseneer, Yves. (2003). I had Barbie in My Brain. In Desirable God: Our Fascination with Images, Idols and New Deities, eds. Burggraeve, Roger, De Tavernier Johan, Pollefeyt Didier and Hanssens Jo, 241-260. Leuven: Peeters.

11. Durkheim, É. (1995). The elementary forms of religious life. Trans. Karen E. Fields. New York: The Free Press.

12. Gobe, M. (2006). Citizen Brand: 10 Commandments for Transforming Brand Culture in a Consumer Democracy. New York: Allworth,

13. Jindra, M. (2000). It's about faith in our future: Star Trek fandom as cultural religion. In: Religion and popular culture in America, (Forbes B.D., Mahan J.H., Eds.), Berkeley: University of California Press.

14. Kahney, L. (2004). The cult of Macintosh. San Francisco: No Starch Press.

15. Kasser, T. (2002). The High Price of Materialism, Cambridge MA: MIT Press,

16. Klein, N. (2010) No Logo: Taking Aim at the Brand Bullies. Vintage: Picado.

17. Muñiz, A.M., Jr., O'Guinn. T. C. (2001). Brand community. Journal of Consumer Research 27(4): 412-432.

18. Pogačnik A., Črnič A. (2014). iReligion: Religious Elements of the Apple Phenomenon. Journal of Religion and Popular Culture. University of Toronto Press. Vol. 26, 3: 356-364. Chichester:

19. Pringle H., Thompson, M. (1999). Brand Spirit: How Cause Related Marketing Builds Brands

20. Wiley C., Rowe, D. (2001). What Do You Mean by Spiritual? In: Spirituality and Psychotherapy, (KingSpooner S., Newnes C., Eds.), Ross-on-Wye: PCCS Books.

21. Raines J. (2012). Marx on Religion. Philadelphia: Temple University Press. 
22. Stolz J. and Usunier J.C. (2018). Religions as brands? Religion and Spirituality in Consumer Society, Journal of Management, Spirituality \& Religion.

23. Santana R.W. and Erickson G. (2016). Religion and popular culture: rescripting the sacred. Jefferson, North Carolina: McFarland \& Company

24. Taylor, C. (2007). A Secular Age. Cambridge, MA: The Belknap Press of Harvard University

25. Tiwari, S. (2003). The (Un)common Sense of Advertising: Getting the Basics Right. New Delhi: Response Books.

26. Twitchell, B. (1999). Lead Us into Temptation: The Triumph of American Materialism. New York: Columbia University Press.

27. Wilson, K. (2008). Jesus Brand Spirituality: He Wants His Religion Back. Nashville, TN: Nelson.

28. Zigmunt. B. (2001). Liquid Modernity. Cambridge, MA: Polity press. 